Oil and Revolution in Mexico 



\title{
Oil and Revolution in Mexico
}

\author{
Jonathan C. Brown
}


University of California Press

Berkeley and Los Angeles, California

University of California Press, Ltd.

Oxford, England

(C) 1993 by

The Regents of the University of California

\section{Library of Congress Cataloging-in-Publication Data}

Brown, Jonathan C. (Jonathan Charles), 1942-

Oil and revolution in Mexico/Jonathan C. Brown.

p. $\mathrm{cm}$.

Includes bibliographical references and index.

ISBN 0-520-07934-5 (alk. paper)

1. Petroleum industry and trade-Mexico-History. I. Title.

HD9574.M6B7 1992

$338.2^{\prime} 7282^{\prime} 0972-\mathrm{dc} 20$

92-25649

CIP

Printed in the United States of America

98765432 I

The paper used in this publication meets the minimum requirements of American National Standard for Information Sciences-Permanence of Paper for Printed Library Materials, ANSI Z39.48-1984. ( 
For G. Franklin and Cynthia Ingalls Brown 
